\title{
Plasma TSH Levels in Rats Exposed to Cold
}

\section{Norimichi KONNO and Toshiyuki KOSEKI}

\author{
Department of Physiology, School of Medicine, Hokkaido University, Sapporo, Japan
}

(Director : Professor Shinji Itoh, M.D.)

Plasma TSH levels in rats exposed to cold were investigated and the following findings were obtained.

Plasma TSH levels elevated soon after exposure to a moderate cold of $8^{\circ} \mathrm{C}$ and reached the peak 30 minutes after exposure. The elevated level of plasma TSH was sustained for only 2 hours. Thereafter, it decreased rapidly toward pre-exposure levels. A relatively low level, but significantly higher than control value, was observed to be maintained in rats kept at $8^{\circ} \mathrm{C}$ for 4 weeks.

During the initial stages of cold exposure at $8^{\circ} \mathrm{C}$ pituitary content of TSH decreased markedly from control value of $803 \mathrm{mU}$ per gland to $624 \mathrm{mU}$ after 6 hours and $303 \mathrm{mU}$ after 24 hours. Percentages of the decrease were 22.3 and 62.3 per cent, respectively, indicating an initial burst of the stored TSH in the adenohypophysis.

Exposure of rats to a mild cold of $15^{\circ} \mathrm{C}$ resulted also in a marked increase in the plasma TSH level after 30 minutes and 2 hours. Thereafter it decreased to the level of preexposure, with an exception of value at 16 hours after exposure. Prolonged exposure at $15^{\circ} \mathrm{C}$ for 4 weeks showed no more increase in the plasma TSH content. A similar but a little prolonged elevation of the plasma TSH was observed in rats exposed to a severe cold of $0^{\circ} \mathrm{C}$.

These results indicate that a bulk of TSH is released from the adenohypophysis in the early phase of cold exposure irrespective of its intensity.

(pp. 1227 1231) 


\section{寒冷曝露によるラット血中 TSH レベルの変動}

$\begin{array}{rrrr}\text { 北海道大学医学部第一生理学教室 } & \text { (主任 } & \text { 伊藤真次教授） } \\ \text { 今 } & \text { 野 } & \text { 則 } & \text { 道 } \\ \text { 小 } & \text { 関 } & \text { 利 } & \text { 行 }\end{array}$

(昭和 41 年 6 月 21 日受付)

緒言

動物を寒冷に曝露した場合，産熱の増加に甲状腺ホルモンが重要な役割を果たしているととは，周知の事 実であり，またてのホルモンの分泌は，下垂体甲状腺刺激ホルモン (TSH) の調節をうけているてとも明ら かである。しかし，寒冷曝露の際の血中 TSH 值の変動，すなわち，下垂体前葉からの TSH の放出の変

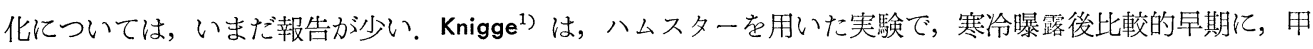
状腺 ${ }^{131}$ I放出速度が上昇することを報告している。また Bottari ${ }^{2}$ ) は，ウサギを Jobin $^{3)}$ はラットを用いて， 寒冷曝露直後に血中 TSH レベルがー過性に急激に上昇すると報告している。一方Brown-Grant $\left.{ }^{4}\right)$ にると， 温和な寒冷下 $\left(5.5-11.5^{\circ} \mathrm{C}\right)$ では甲状腺 ${ }^{131} \mathrm{I}$ 放出速度が元進するが，激しい寒冷は，むしろてれを抑制すると いう。しかしその実験は直接血中 TSH レベルを測定したものでないから, 果して下垂体前葉からの TSHの の放出が，寒冷の程度によつて異つた様相を呈するかどうか明らかでない．著者らはての点を明らかにする ために，ラットを種々な程度の寒冷に曝露し，血中 TSH レベルの時間的変動を検討した。

\section{実験材料及び方法}

実験動物としては，体重150〜250g の Wistar 系ラットを用いた。性別は，血中 TSH 測定の実験では， 雌雄を区別しなかつたが，下垂体前葉の TSH 含量は雄ラットのみについて測定した。動物は28Cで10日間 以上飼育した後, $15^{\circ} \mathrm{C}, 8{ }^{\circ} \mathrm{C}$, および $0{ }^{\circ} \mathrm{C}$ 寒冷環境に移し, 種々の期間後, 断頭屠段によつて血液および 下垂体前葉を採取した，血液は遠沈後血漿を分離し，数匹分をプールして TSH 測定に用いた。一方下垂体 前葉は，重量を測定した後， 4 個の前葉組織を $0.05 \%$ 酢酸生理食塩水 $2 \mathrm{ml}$ 中で homogenize し，遠沈後上 清を生理的食塩水で稀釈し，TSH 測度に供した。

TSHの測定は以前に小関が報告したでとく ${ }^{25)}$ McKenzie-野口法6) に基ずき，次のように行つた。すなわち $20^{\circ} \mathrm{C}$ 前後の室温で自家繁殖したS-M系マウスを体重 $12 \mathrm{~g}$ 前後に達した時からオリエンタル固形飼料 $\mathrm{M}-\mathrm{F}$ で飼 育した。実験 5 日前に Carrier-free ${ }^{131} \mathrm{I} 10 \mu \mathrm{c}$ を腹腔内に注射， 5 時間後に L-thyroxine $10 \mu \mathrm{g}$ を皮下注射 し，その直後より飲料水に $0.1 \%$ の割で甲状腺末を加え，さらに24時間後に L-thyroxine $5 \mu \mathrm{g}$ を与えた。被 験液は $0.5 \mathrm{ml} ゙$ つマウス尾静脈より注入し，その直前および 2 洔間後に眼静脈叢より採血，その $0.1 \mathrm{ml}$ につ いて放射能を東芝製 Well-type Scintillation Counter で測定し，変化を百分率であらわした。

\section{実 験 結 果}

\section{1）寒冷曝露時のラット血中 TSH レベル}

あらかじめ $28^{\circ} \mathrm{C}$ の室内で10日間以上飼育したラットを $15^{\circ} \mathrm{C}$ 室内に移した時，血中の TSH レベルは， Fig. 1 に示すように，30分で著明に上昇して最高値を示し，2 時間後でもほぼ同程度の高い値が得られたが， しかし 6 時間後には著しく低下し，曝露前のレベルに戻つた。その後16時間後に，軽度ながら再び上昇した が，以後 4 週間後まで曝露前の低い值を維持した。

$8^{\circ} \mathrm{C}$ の寒冷に曝露した場合においても(Fig. 2)，15分ですでに血中 TSH 值の明らかな上昇がみられ，30分 第 42 巻 第 11 号 
Fig. 1 Time course of plasma TSH level in rats exposed to a mild cold $\left(15^{\circ} \mathrm{C}\right)$. The mean values are shown with S.E. The numbers shown on the top of each column represent the number of mice and rats respectively.

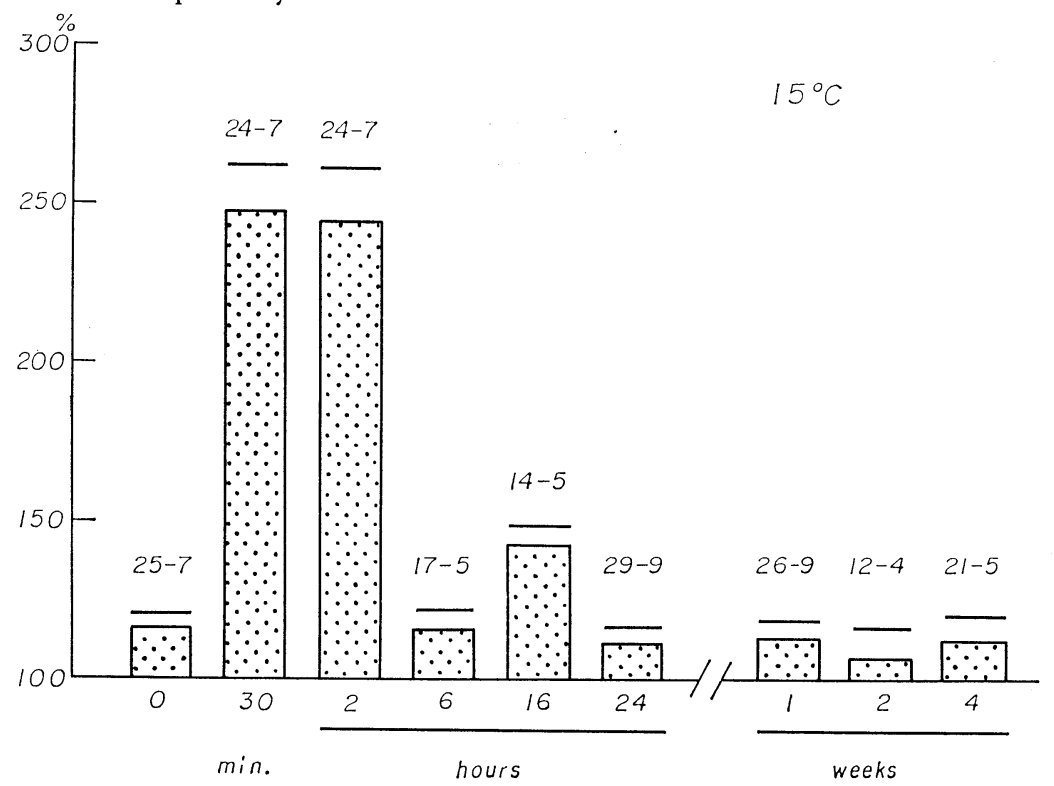

Fig. 2 Time course of plasma TSH level in rats exposed to a moderate cold $\left(8^{\circ} \mathrm{C}\right)$.

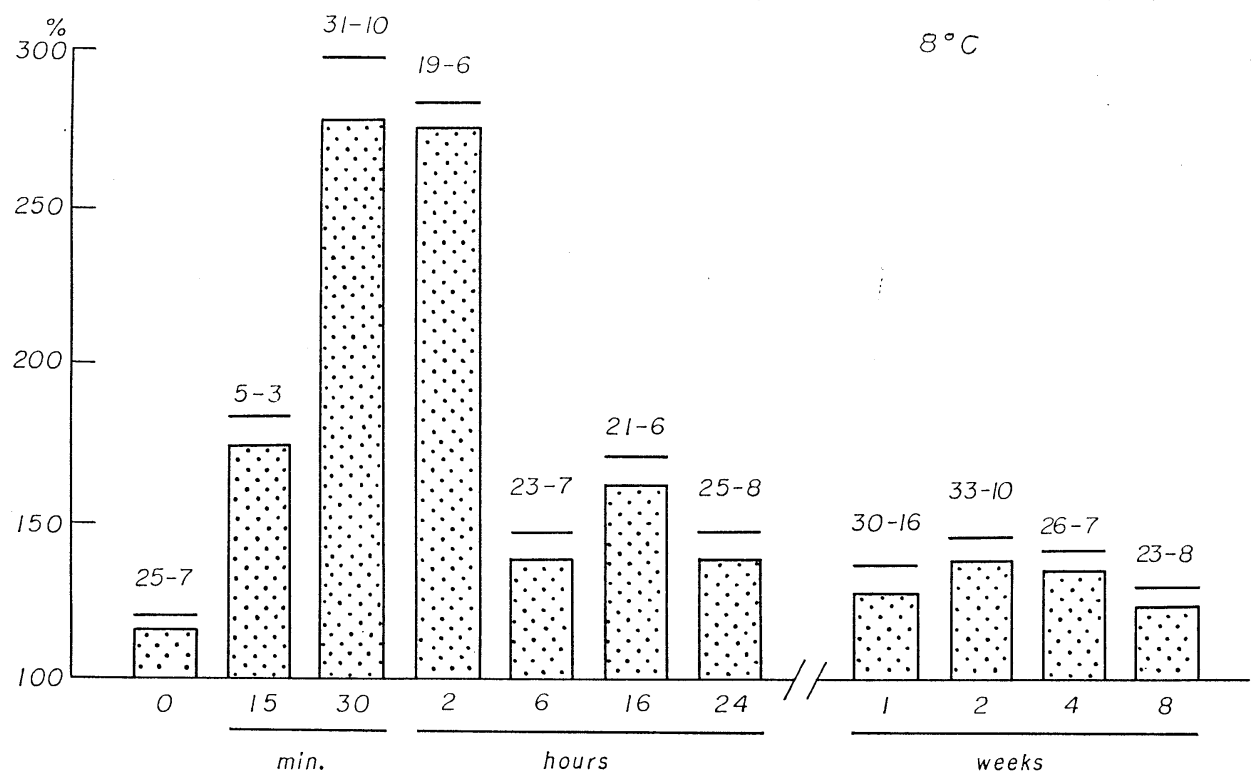

後に最高に達した。しかしその後速やかに下降し，6時間後の值は寒冷曝露前の值にくらべ，軽度に高いレ ベルにとどまつた．測定はその後 8 週間まで種々の期間について行つたが，とくに著しい変動を示さず，ほ ぼての值が保たれていた。 
次に $0{ }^{\circ} \mathrm{C}$ 寒冷に曝露した場合 (Fig. 3)， $8{ }^{\circ} \mathrm{C}, 15$ ${ }^{\circ} \mathrm{C}$ の場合と同様曝露後30分で血中 $\mathrm{TSH}$ 值は最高に 達した，その後血中 $\mathrm{TSH}$ 值の下降は上記 2 つ場 合にくらべてやや緩徐で，6時間後でもかなり高い 值を示し，24時間後になつて，はじめて曝露前の值 に戾つた.

\section{2）寒冷曝露による下垂体 TSH 含量の変化}

上述の如き血中 TSH レベルの変動に際して，下 垂体前葉の TSH 量はいかなる変動があるかを知る ため, $8{ }^{\circ} \mathrm{C} の$ 寒冷に曝露したラットの前葉の TSH 含量を測定した (Table 1)。寒冷曝露後 6 時間の $\mathrm{TSH}$ 含量は $624 \mathrm{mU} / \mathrm{Gland}$ であつて，対照值803 $\mathrm{mU}$ にくらべ明らかに減少していた。更に24時間後 には $303 \mathrm{mU}$ になり，対照值の37.7\%にまで低下し た. この結果からみて，急性寒冷曝露に際して下垂 体前葉から TSH が急速に放出せられ，その含量が 著明に減少すると考学られる。
Fig. 3 Time course of plasma TSH level in rats exposed to an intense cold $\left(0^{\circ} \mathrm{C}\right)$

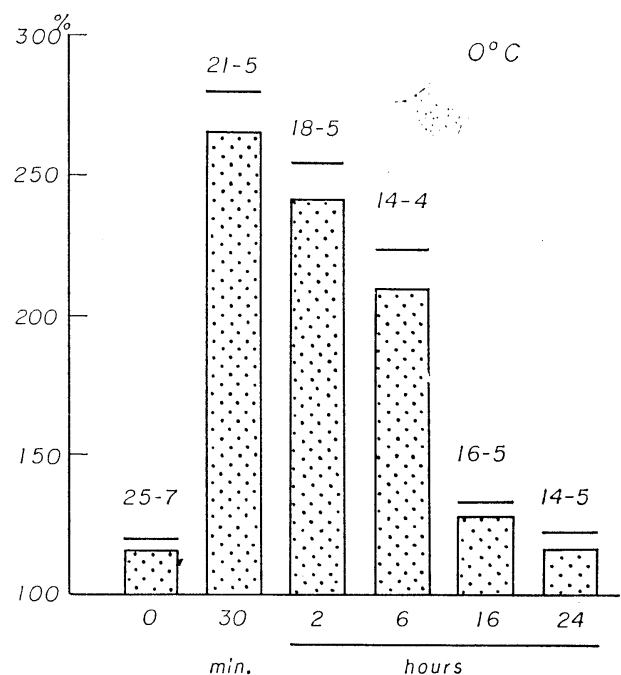

Table 1. Influence of acute exposure to cold $\left(8^{\circ} \mathrm{C}\right)$ upon the $\mathrm{TSH}$ content in the anterior pituitary

\begin{tabular}{|c|c|c|c|c|c|}
\hline & \multirow{3}{*}{$\begin{array}{l}\text { No. of } \\
\text { rats }\end{array}$} & \multirow{3}{*}{$\begin{array}{l}\text { Average } \\
\text { Body Weight } \\
\qquad(\mathrm{g})\end{array}$} & \multicolumn{3}{|c|}{ Anterior Pituitary } \\
\hline & & & \multirow{2}{*}{$\begin{array}{l}\text { Weight } \\
(\mathrm{mg})\end{array}$} & \multicolumn{2}{|c|}{ TSH content } \\
\hline & & & & $\mathrm{mU} /$ gland & $\mathrm{mU} / \mathrm{mg}$ \\
\hline Control $\left(28^{\circ} \mathrm{C}\right)$ & 4 & 184 & 7.5 & $803 \quad(992-682)$ & $107(132-91)$ \\
\hline Cold 6 hours & 4 & 164 & 7.9 & $624 \quad(883-467)$ & $106(150-79)$ \\
\hline 24 hours & 4 & 188 & 7.5 & 303 (348-263) & $40 \quad(46-35)$ \\
\hline
\end{tabular}

Numbers in parentheses represent $95 \%$ codfidence limits.

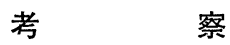

動物を寒冷に曝露すると，血中の TSH レベルが急速にかつ著明に上昇することは, ハムスター ${ }^{1)}$ ，ウサギ2), ラッドにといてすでに報告されており，我々もてれを確認した。

Brown-Grant ${ }^{4,5)}$ は，動物を激しい寒冷に曝露すると，甲状腺 ${ }^{131} \mathrm{I}$ 放出はむしろ抑制されると報告し，乙れ は下垂体からの TSH の分泌が抑制せられるためであると推論したが，我々の得た結果では，血中 TSH レ ベルは寒冷の程度に関係なく，一様に早期に著明な上昇を示すととがわかつた。 Brown-Grant の報告を含め て，今までに報告された文献によると，Stress ${ }^{7-11)}$ あるいは ACTH 及び Cortisone ${ }^{12-17)}$ そつて甲状腺機 能が抑制されるといわれており，乙れにはTSHの分泌抑制によるとするものと ${ }^{\left.10)^{12} 13\right)}$ ，直接甲状腺機能が 抑制せられたためであるというものとがある ${ }^{14 \sim 16)}$. Epstein ら ${ }^{14}$ は，下垂体摘出ラットに外因性に TSH を 与光，甲状腺 ${ }^{131} 1$ 摂取能を上昇させておいて，てれに ACTH または Cortisone を与えると甲状腺 ${ }^{131}$ I 揕取 能が低下するという。また Shellabarger ${ }^{15)}$ は，TSH の分泌が極めて少ない生後2-3日のヒヨコにCortisone を与えると，甲状腺機能が抑えられると述べている。乙れらの報告は，AGTH または Cortisone が直接甲 状腺機能を抑制することを暗示している。一方 Knigge $\left.{ }^{19}\right)$ は八ムスターを寒冷に曝露した場合，曝露後早期 
の甲状腺機能の変化に対して，Corticosteroids がとくに大きい影響を与えるてとはないとしており，また Jobin ${ }^{3)}$ も先に副腎を摘出した動物を寒冷に曝露した場合でも，やはり曝露後急激に血中 TSH レベルが上 昇するとしている，更に D'Angelo20)はモルモットを寒冷に長期間曝露した場合に，下垂体中の ACTH 含 量が著しく上昇し，尿中えの Corticoids の排沮が艺進しているにもかかわらず，血中の TSH 濃度は上昇 しているという，徒つててれらの報告は，激しい寒冷が非特異的な Stress として作用し，TSHの分泌を抑 制するという考光に疑問を投ずるものであり，我々の得た結果も Kraicer ${ }^{17)}$ が述べたように，Stress 下にお ける血中 TSH の変化に対して副腎皮質ホルモンは関与しないという見解に一致するものと考元られる.

ところが最近 Sakiz ${ }^{21)}$ は，Stress によつて ACTH の分泌が高まつたラットに外因性に TRF を与えて も血中 TSH レベルの上昇が著明でない事実を見出し，てれはStressによつて，ACTH の分泌が杂進し， 下垂体にわける TSH 分泌機序が ACTH え移行したためであると説明した。動物を寒冷に曝露した場合 に，血中 TSH レベルは一過性に上昇するのみで，寒冷曝露を継続してもその後は血中 TSH レベルに大 きい上昇を見なかつたのは (Fig. 1，2)，Sakiz らのいうように，下垂体ホルモン分泌機序の「移行」があり， 寒冷刺激による ACTH の分泌充進に伴い，TSH の産生が防げられたためかも知れない.すなわち，TSH の「放出」があつても「産生」が抑制される可能性が考えられ，乙の場合当然下垂体のTSH 含量が急激な 減少を示すととになるであろう。

寒冷曝露によつて大量の TSH が一挙に放出されると，それによつて恐らく甲状腺は強く刺激され，大量 の甲状腺ホルモンを分泌するととになるものと思われる。更にTSH が向甲状腺作用以外に甲状腺外作用を もつととも考慮に入れる必要があるかも知れない，Tonove ら ${ }^{22}$ は，in vitro :の実験でマウスの腹筋による ${ }^{131}$ I-Thyroxine の Uptake が TSH によつて促進するてとをみとめた。 従つて寒冷曝露にさいして大量の TSH が放出されると，末梢組織における Thyroxine の掑取が方進し Thyroxine の产熱作用が促進せら れるかも知れない，また TSH 亿は遊離脂肪酸 (FFA) 放出作用のあるてとが知られている. Freinkel ${ }^{23)}$ 亿よ ると，ラットの副辠丸脂肪組織を TSH と共に incubate すると，組織及び Medium 中の FFA 濃度が上 昇するという。また Sisson ${ }^{24}$ は $\mathrm{TSH}$ が Lipolysis を促進する以外に，副殬丸脂肪組織の酸素消費量， Glucose 酸化をたかめると報告している。我々も副䔂丸脂肪組織についててれら TSH の甲状腺外作用を確 認した (未発表)。寒冷曝露時の産熱に脂肪の利用が重要なととは従来しばしば論議されているとてろであり， TSH による FFA の放出も生理的意義をもつかも知れない. しかしての点についてはなお決定的でなく今 後の研究にまたなければならない.

\section{要 約}

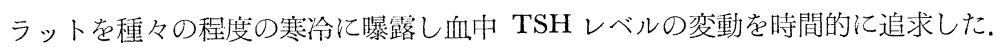

ラットを $15^{\circ} \mathrm{C}$ の寒冷に曝露した場合には, 曝露後30分で血中 $\mathrm{TSH}$ レベルは最高に達し, その後速やかに 下降し，6時間後には曝露以前の值に厌つた. $8{ }^{\circ} \mathrm{C}$ 寒冷に曝露した場合も，血中 TSH の急激な上昇がみ られ，曝露後30分で最高に達し，その後速やかに下降し 6 時間後の值は寒冷嚗露前の值にくらべ，軽度に高 いレベルにとどまつた，更にての値は 8 週間後まで維持された。 $0{ }^{\circ} \mathrm{C} の$ 寒冷に曝露した場合でも，血中TSH 値は，30分後において最高値を示したが，その後の TSH 值の下降は $8{ }^{\circ} \mathrm{C}, 15^{\circ} \mathrm{C}$ 場合にくらべて緩徐であつ た. $8^{\circ} \mathrm{C}$ 寒冷に曝露したラットの下垂体前葉 TSH 合量は，曝露後 6 時間ですでそ低下し，24時間後には 曝露以前の $37.7 \%$ にまで減少した。

終りに臨み，御指導，御校閲を睗わりました恩師伊藤真次教授に哀心より感謝の意を表します.

\section{引用 文 献}

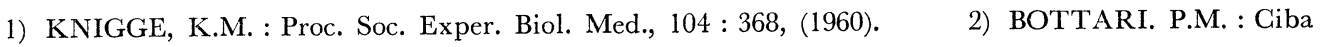
Found. Colloq. Endocrinol., $11: 52$, (1957).

3) JOBIN, M. and FORTIER, G. : Fedr. Proc., $24: 149$, (1965).

4) BROWN-GRANT, K. : J. Physiol., $131:$ 52, (1956).

5) BROWN- 
GRANT, K., VON EUler, C., HARRIS, G.W. and REIChliN, S. : J. Physiol., $126: 1$, (1954). 6) YAMAZAKI, E., A. NOGUCHI, S. SATO and SLINGERLAND, D.W. : J. Clini. Endocrinol., $21: 1127$, (1961). $\quad$ 7) WILliAMS, R., JAFFE, H., and KEMP, G. : Am. J. Physiol., 159 : 291 , (1949). $\quad$ 8) PASCHKiS, K.E., GANTAROW, A., EBERHARD, T. and BOYLE, D. : Proc. Soc. Exper. Biol. Med., $73: 116$, (1950).

9) SOFFER, L.J., GABRILOVE, J.L. and JAILER, J.W. : Proc. Soc. Exper. Biol. Med., 71 : 117, (1949). 10) BOGOROCH, R. and TIMIRAS, P. : Endocrinology, 49 : 548, (1951). 11) VAN MIDDLEWORTH, L. and BERRY, M.M. : Amer. J. Physiol., 167 : 576, (1951). $\quad$ 12) HILL, S.R. JR., REISS, R.S., FORSHAM, P.H. and THORN, G.W. : J. Clin. Endocr., $10: 1375$, (1950). 13) BROWN-GRAN, K. : J. Physiol. 131 : 58, (1956). 14) EPSTEIN, D., GANTAROW, A., FRIEDLER, G. and PASGHKIS, K.E. : Proc. Soc. Exper. Biol. Med., 82 : 50, (1953). 15) SHELLABARGER, G.J. : Endocrinology, $55: 100$, (1954). 16) PERRY, W.F. : Endocrinology, 49 : 284, (1951). 17) MONEY, W.L., KIRSGHNER, L., KRAINTZ, L., MERRILL, P. and RAWSON, R.W. : J. Glin. Endocr., $10: 1282$, (1950). 18) KRAICER, K., DUECOMMUN, P., JOBIN, M., RERUP, C., VAN REES, G.P. and FORTIER, G' : Feder. Proc., 22 : 507, (1963). 19) KNIGGE, K.M., GOODMAN, R.S. and SOLOMON, D.H. : Am. J. Physiol., $189:$ 415, (1957). 20) D’ANGELO, S.A. : Feder. Proc., $19: 51$, (1980). 21) SAKIZ, E. and GUILLEMIN, R. : Endocrinology, 77 : 797, (1965). 22) TONOUE, T., SUZUKI, M. and YAMAMOTO, K. : Endocrinology, $72: 345$, (1963). 23) FREINKEL, N. : J. Clin. Invest., $49: 476,(1961) .24)$ SISSON, J.C. : Endocrinology, $74: 643$, (1964). 25) 小関利行 : 日本 内分泌学会雑誌, $40: 1027$, (1965). 